\title{
? JURNAL BASTRINDO
}

\section{Pemerolehan Fonem Bahasa Ibu Anak Usia 2,6 Tahun: Studi Kasus pada "Rasyid Hidayat"}

\author{
M. Zakaria*; I Nyoman Sudika ; Siti Rohana Hariana Intiana* \\ *Pendidikan Bahasa dan Sastra Indonesia, FKIP Universitas Mataram \\ Email: zakaria281095@gmail.com
}

\begin{abstract}
Abstrak: Penelitian ini membahas tentang pemerolehan fonem bahasa ibu atau pertama pada anak usia 2,6 tahun. Tujuan dari penelitian ini yaitu mendeskripsikan bentuk dari pemerolehan fonem bahasa ibu dalam studi kasus pada Rasyid Hidayat usia 2,6 tahun dengan melihat fonem-fonem bahasa yang sudah dikuasai. Pendekatan yang digunakan dalam penelitian ini adalah pendekatan deskriptif kualitatif. Pendekatan ini mencoba menggambarkan dan memahami sesuatu terkait fenomena yang akan diteliti berdasarkan perspektif peneliti, yaitu bentuk pemerolehan fonem bahasa ibu pada Rasyid Hidayat. Adapun metode yang digunakan dalam penelitian ini adalah metode simak dan metode cakap. Teknik yang digunakan dalam melaksanakan metode tersebut adalah teknik catat dan rekam. Penyajian hasil analisis data dalam penelitian ini adalah secara formal dan informal. Penelitian tentang pemerolehan fonem bahasa ibu pada anak usia 2,6 tahun, peneliti menemukan bentuk-bentuk fonem yang sudah dikuasai oleh Rasyid Hidayat. Adapun fonem bahasa yang sudah dikuasai adalah (l) semua fonem vokal, yaitu /a/, /i/, /u/, /e/, dan /o/ yang menduduki semua posisi dalam setiap kata, (2) fonem konsonan yang sudah dikuasai dan belum semuanya menduduki semua posisi dalam kata pada usia 2,6 tahun yaitu adalah /p/, /b/,/m/,/n/,/t/, /h/,/s/,/c/,/w/,/y/,/q/, dan /k/.
\end{abstract}

Kata Kunci: Pemerolehan Bahasa Ibu, Fonem, Psikolinguistik

\section{Acquisition of Phonemes for Mother Tongue Children Aged 2,6 Years: A Case Study in "Rasyid Hidayat"}

Abstract: This study discusses about the phonological acquisition of mother tongue or first language of a child, 2.6 years old, namely Rasyid Hidayat. The purpose of this study is to describe the forms of phonological acquisition of mother tongue of Rasyid Hidayat by analyzing the phonemes of language that have been mastered. In this study, the researcher uses descriptive qualitative approach which describes and gives understanding about language phenomenon that the researcher want to analyze based on the researcher's point of view. The data collected were gained from recording and note taking. In presenting the data analyzed, the researcher uses formal and informal way. The findings show that the participant has mastered l) all vowel phonemes such as /a/, /i/, /u/, /e/, and /o/ which have occupied all positions in many words, 2) consonant phonemes such as $/ \mathrm{p} /, / \mathrm{b} /, / \mathrm{m} /, / \mathrm{n} /, / \mathrm{t} /, / \mathrm{h} /, / \mathrm{s} /, / \mathrm{cl}, / \mathrm{w} /, / \mathrm{y} /, / \mathrm{q} /$, and $/ \mathrm{k} /$ where not all of them have already occupied all positions in some words.

Keywords: Language acquisition, Phonology, Psycholinguistics

\section{PENDAHULUAN}

Setiap orang sudah dibekali dengan kemampuan berbahasa. Berbahasa itu sendiri merupakan suatu proses yang kompleks dan rumit yang terjadi begitu saja, dan terus 
mengalami perkembangan mulai sejak lahir sesuai dengan tahap-tahap usianya. Kerumitan ini terlihat ketika anak dalam memproduksi ujaran dengan menyederhanakannya. Penyederhanaan ini disebabkan oleh kebelum-mampuan alat ujar dalam produksi ujaran tersebut. Kemampuan dalam produksi ujaran ini akan terus berkembang (dalamYogatama, 2011).

Dardjowidjojo (2016) menjelaskan bahwa pemerolehan bahasa merupakan bagian penting dari kehidupan seseorang. Pemerolehan bahasa didefinisikan sebagai proses penguasaan atau perkembangan bahasa yang dilakukan oleh anak secara alami pada waktu dia belajar bahasa ibunya, bahasa pertama, yang dikenal oleh seorang anak. Tentu pemerolehan bahasa pada anak berbeda dengan pembelajaran bahasa yang dilakukan pada tataran formal, setelah anak menguasai bahasa ibunya. Begitu pula pada anak usia 2,6 tahun yang masih mengalami pemerolehan bahasa ibunya. Richar (dalam Salamah, 2015) juga menjelaskan, pemerolehan bahasa tersebut merupakan proses bawah sadar, atau proses mental atau kognitif yang mengarah pada kompetensi berbahasa dan penguasaan tata bahasa. Hal ini sesuai dengan pandangan dari Chomsky bahwa anak sejak alahir sudah dibekalai dengan piranti yang membuat anak - di mana pun dia berada - mampu memperoleh bahasanya. Lebih lanjut Strazny, pemerolehan bahasa pertama adalah proses seorang anak baik laki-laki atau perempuan belajar bahasa ibu mereka (dalam Tussolekha, 2015). Kiparsky menjelaskan bahwa anak dalam pemerolehan bahas mempelajari tata bahasa orangtuanya. Kemudian dia menyusun atau membangun suatu tata bahasa yang lebih sederhana yang dibuatnya sendiri (dalam Tarigan, 1984).

Pemerolehan fonem ini berkaitan dengan pemerolehan suatu lambang bunyi yang membedakan makna atau arti pada kata. Pemerolehan fonem ini bagian dari fonem. Pemerolehan fonem bahasa pada anak adalah pemerolehan suatu lambang bunyi pada saat proses pemerolehan bahasa pertama. Pemerolehan bahasa pada anak terjadi atau dialami oleh semua anak, dan hal yang menarik dari pemerolehan fonem ini adalah bahwa perkembangan yang terjadi juga hampir sama antara anak yang satu dengan anak yang lain, khususnya pemerolehan bahasa pertama. Sebagaimana yang dijelaskan oleh Arifuddin (2010), bahwa pemerolehan bahasa pertama atau bahasa ibu anak-anak di seluruh dunia sama. Anak yang belum mampu mengucapkan bunyi /// atau /r/ akan mengganti dengan bunyi-bunyi yang lain sesuai dengan bunyi yang sudah dikuasinya. Dalam pemerolehan fonem juga, bahwa konsonan hambat $(/ \mathrm{p} /-/ \mathrm{b} /)$ lebih dulu dikuasai oleh anak daripada konsonan frikatif dan afrikatif. Begitu pun dengan bunyi vokal, bahwa vokal /a/ lebih dulu muncul kemudian disusul dengan vokal/u/ dan /i/. Dia melanjutkan, kesamaan ini tidak hanya disebabkan oleh persamaan unsur biologi dan neurologi bahasa, tetapi juga oleh adanya aspek mentalitas bahasa sebagaimana yang dikemukakan oleh Chomsky melalui teori mentalitas.

Teori yang dikemukan oleh Chomsky menekankan bahwa anak sudah memiliki kompetensi bahasa yang dibawa sejak lahir yang dikenal dengan istilah piranti. Chomsky menyarankan bahwa kita harus meyakini bahwa kompetensi bahasa sebagai sebuah sistem yang abstrak yang menentukan perilaku, sebuah sistem yang dibangun oleh kalimat yang jumlahnya tidak terbatas yang disebut generative grammar. Lebih lanjut dijelaskan oleh Chomsky bahwa bahasa bukan merupakan sekumpulan kebiasaan lingkungan bahasanya, namun merupakan sebuah sistem kaidah yang terinternalisasi. Proses pemerolehan bahasa tidak ditentukan oleh peniruan, penguatan, dan pembentukan kebiasaan, tetapi oleh adanya kapasitas dalam yang ada pada diri anak tersebut. Pandangan Chomsky dalam pemerolehan bahasa anak ini adalah paham mentalisme (dalam Arifuddin, 2010).

Chomsky dengan pandangan bahwa seorang anak sudah memiliki kemampuan berbahasa sejak lahir yang dikenal dengan piranti atau sifat bawaan. Terlepas dari itu, Skinner dan pendukungnya berpandangan bahwa bahasa merupakan bagian penting dari keseluruhan perilaku seseorang, sehingga bahasa itu menjadi perilaku verbal manusia. Pandangan Skinner ini dibangun dengan tiga komponen, yaitu stimulus, respon, dan 
penguatan. Dari pandangan Skinner ini dikenal dengan paham behaviorisme. Pandangan ini menganggap bahwa anak dilahirkan seperti 'piring kosong' atau dikenal dengan 'teori tabula rasa'. Berbeda dari Chomsky dan Skinner, Piaget sendiri berpandangan bahwa pemerolehan bahasa merupakan salah satu aspek dari perkembangan kognitif secara keseluruhan yang pada awalnya sangat berkaitan dengan perkembangan serangkaian skema motoris saraf yang dikontrol secara fisiologis oleh otak manusia (dalam Arifuddin, 2010). Pandangan ini juga mengatakan bahwa bahasa itu salah satu di antara beberapa kemampuan yang berasal dari kematangan kognitif. Jadi, urutan-urutan perkembangan kognitif menentukan urutan perkembangan bahasa (dalam Fatmawati, 2015).

Ketiga pandangan di atas tentu tidak bisa dipandang dengan sebelah mata. Sebab, dalam pemerolehan bahasa pada anak tentu ada beberapa faktor yang mempengaruhi baik dalam diri anak (kemampuan berbahasa dan kematangan kognitif) dan lingkungan (stimulus-respon atau masukan). Sebagaimana yang terjadi pada subjek penelitian, yaitu adanya interaksi dengan orang sekitarnya.

Mengenai pemerolehan bahasa pertama, Tarigan (2011) mengatakan bahwa pemerolehan bahasa pertama memang bersifat "primer" minimal dalam dua hal: dari segi urutan (tidak mendahului bunyi satu dengan bunyi yang lain) memang yang "pertama" dan dari segi kegunaan (hampir dipakai selama hidup). Dalam hal pemerolehan fonem bahasa pada anak, tentu melalui urutan sesuai dengan tahapan maupun kesiapan atau kematangan neurobiologi (Perkemabngan biologi dan otak). Urutan pemerolehan bunyi yang diramalkan oleh Jakobson, yaitu konsonan lambat lebih dahulu diperoleh daripada frikatif dan afrikatif serta yang terakhir bunyi /l/ dan /r/, pada dasarnya sejalan dengan data yang dikumpulkan oleh sejumlah pakar seperti Clark dan Clark, Ervin - Trip, dan Foss dan Hakes. Data tersebut menunjukkan bahwa anak lebih dahulu membunyikan /p/, /b/, /d/, dan /t/ daripada bunyi /f/ dan /s/ (dalam Chaer, 2009: 204). Hal senanda terdapat juga dalam Sudika (2015: 58) bahwa "konsonan hambat diperoleh lebih awal daripada konsonan frikatif dan afrikatif, dan konsonan frikatif lebih awal diperoleh daripada konsonan afrikatif".

Mengenai pemerolehan fonem bahasa ibu perlu dibedakan antara bahasa ibu dan bahasa sang ibu. Bahasa ibu adalah bahasa pertama yang dikuasai atau diperoleh oleh anak. Bahasa ibu adalah padanan untuk istilah Inggris native language. Sedangkan Bahasa sang ibu sendiri adalah bahasa yang dipakai oleh orang dewasa pada waktu berbicara dengan anak yang sedang dalam proses pemrolehan bahasa ibunya.

Dalam proses pemerolehan fonem bahasa ibu pada anak melalui tahap-tahap. Tahaptahap yang dilalui oleh anak tidak hanya melihat berdasarkan tahun kalender, tetapi perlu juga memperhatikan kematangan neurobiologi. Artinya, pada tahap perkembangan neurobiologis mana seorang anak dapat mengucapkan bunyi-bunyi tertentu. Hal ini dikarenakan anak yang lebih kecil memperoleh fonem bahasa lebih cepat dari anak yang lebih tua, atau sebaliknya. Oleh karena itu, perkembangan neurobiologis juga perlu menjadi patokan dalam melihat perkembangan pemerolehan bahasa pada anak.

Menurut Arifuddin (2010), tahap-tahap pemerolehan bahasa anak secara universal dibagi menjadi empat tahap, yaitu praujaran, meraban, tahap satu kata, dan tahap penggabungan kata. Pada tahap praujaran dan meraban, bunyi-bunyi yang keluar dari anak masih belum dapat dikatakan ujaran. Tahap ini dimula sejak lahir sampai usia 12 bulan. Pada tahap satu kata ditandai dengan mulai dihasilkannya tanda-tanda bahasa sesungguhnya. Kata-kata yang dihasilkan sering kali disederhanakan. Dan pada tahap penggabungan kata menjelang usia 2,5 tahun, kebanyakan anak-anak akan berbicara dengan menggunakan kalimat yang mengandung banyak kata, walaupun tata bahasanya tidak sempurna. Pada usia 5-6 tahun anak sudah menyerupai ujaran orang dewasa.

Pemerolehan bahasa anak merupakan suatu proses penguasaan bahasa yang dilakukan oleh anak secara natural pada waktu dia belajar bahasa ibunya, sebagaimana yang telah dipaparkan di atas. Kenyataan di lapangan memberikan gambaran bahwa kemampuan 
berbahasa hanya ada pada manusia, karena sampai saat ini belum ada penelitian yang mengatakan binatang memiliki kemampuan berbahasa. Hal ini menggambarkan kepada kita keunikan manusia (anak) dalam memproduksi bahasa atau ujaran. Salah satu contohnya yaitu Rasyid Hidayat yang begitu aktif berinteraksi, baik secara verbal maupun nonverbal dengan orang di sekitarnya, menampakkan perolehan bahasa pertama, bahasa ibunya, bahasa Sasak. Pada usia ini Rasyid sudah mamasuki ujaran banyak kata atau penggabungan kata. Sebenarnya ujaran penggabungan kata atau banyak kata ini sudah terlihat pada usianya yang 2,2 tahun. Tidak hanya itu, memandang bahwa adanya keuniversalan dalam pemerolehan fonem dan menarik untuk diteliti. Misalnya, ujaran dari Rasyid Hidayat [ayIn]-/salin/ (bahasa Sasak) artinya 'ganti' dan [dawən]-/dalem/ (bahasa Sasak) artinya 'dalam'. Ujaran tersebut menunjukkan bahwa bunyi /1/ dalam kata /salin/ dan /dalem/, dalam bahasa Sasak diganti dengan bunyi /w/ dan /y/, bahkan menggantinya dengan bunyi /n/. Hal ini menunjukkan bahwa anak yang belum mampu memproduksi bunyi /1/ akan menggantinya dengan bunyi /w/, /y/ atau /n/. Keunikan dan kerumitan, keuniversalan bunyi, serta sejauh mana pemerolehan bahasa anak pada bidang fonem inilah mendorong peneliti untuk melakukan penelitian yang merupakan studi kasus pada anak yang bernama "Rasyid Hidayat", sehingga peneliti mengangkat judul "Pemerolehan Fonem Bahasa Ibu pada Anak Usia 2,6 Tahun: Studi Kasus pada "Rasyid Hidayat".

Penelitian ini mengungkapkan tentang bentuk pemerolehan fonem bahasa ibu pada usia 2,6 tahun yang merupakan studi kasus pada Rasyid Hidayat (bahasa ibu, Bahasa Sasak). Penelitian ini bertujuan untuk mendeskripsikan bentuk pemerolehan fonem bahasa ibu pada anak usia 2,6 tahun.

\section{LANDASAN TEORI}

Penelitian mengenai pemerolehan bahasa pada anak menarik perhatian para ahli untuk menelaahnya. Dalam proses pemerolehan bahasa tentu banyak hal yang memperngaruhinya, baik secara mental maupun lingkungan bahasa.

\section{Teori Pemerolehan Bahasa}

Terkait dengan pemerolehan bahasa anak, dalam hal ini pemerolehan bahasa ibu, terdapat beberapa teori, antara lain.

\section{a) Teori Behaviorisme}

Teori behaviorisme melihat pada pemberian stimulus dan respon. Artinya bahwa lingkungan bahasa anak memberikan masukan kepada anak tersebut, dan sebagai timbal balik dari masukan yang diberikan, anak akan meresponnya. Dalam pandangan ini adanya sebuah rangsangan dalam proses pemerolehan suatu bunyi bahasa. Sehingga stimulus yang diberikan dan respon yang tepat akan melahirkan suatu perilaku terus menerus mengikuti proses yang tepat (Fatmawati, 2015). Sementara itu Chaer (2009) menjelaskan bahwa pandangan ini beranggapan bahwa anak laksana piring kosong. Artinya bahwa anak dalam proses memperoleh bahasa pertamanya tidak berperan aktif, dengan kata lain lingkungan bahasanya lah yang berperan aktif dengan rangsanganrangsangan yang diberikan atau yang diterima dari lingungan bahasa. Kemampuan yang didapatan tidak lain adalah bentuk dari proses stimulus-respon dan kemampuan untuk meniru apa yang masu dari lingkungan bahasa.

\section{b) Teori Nativisme Chomsky}

Teori ini berpandangan bahwa manusia tidak lahir tanpa kemampuan berbahasa, seperti yang dianggap oleh kaum behavior. Kemampuan berbahasa hanya dimiliki oleh manusia, bukan pada binatang. Dalam pandangan tersebut, menusia sudah dibekali dengan suatu sistem yang dinamakan piranti, sehingga anak di mana pun ia berada akan 
mampu memperoleh bahasanya sendiri, tanpa atau dengan lingkungannya. Pandangan ini memberikan penjelasan bahwa bahasa tersebar secara genetik dan perkembangannya memlalui proses yang teratur, bukan terjadi secara acak. Pandangan ini juga berasumsi bahwa bahasa dapat dikuasai oleh anak dalam masa yang relatif singkat dan lingkunga tidak menyediakan informasi yang cukup lengkap dalam proses pemerolehan bahasa. (Fatmawati, 2015).

Chomsky menyampaikan teorinya bahwa anak memang sudah dibekali dengan suatu sistem bahasa, sehingga mempunyai kemampuan dalam berbahasa. Hal ini didasarkan ada aspek biologi dan neurologi. Secara biologi, misalnya mulut, memiliki bentuk yang berbeda dengan makhluk yang lain. sedangkan dalam neurologi berkaitan dengan otak, bahwa manusia memiliki bagian khusus dalam mengontor aktivitas berbahasa dan tidak ditemukan pada binatang. Dan keberadaan suatu sistem bahasa ini sudah ada sejak lahir. (dalam Arifuddin, 2011). Dijelaskan lebih lanjut (dalam Dardjowidjojo, 2016) bahwa anak tidak ditentukan oleh lingkungan melainkan oleh piranti tersebut dan bersifat universal, sebagaimana yang dianggap oleh kaum behavior dengan teori 'piring kosong.

c) Teori Kognitivisme

Jean Piaget merupakan pelopor dari teori ini. Dia mengatakan bahwa dalam pemerolehan bahasa tidak terlepas dari kematangan kognisi seseorang. Jadi, urutanurutan perkembangan kognitif menentukan urutan perkembangan bahasa (dalam Fatmawati, 2015).

Jean Piaget (dalam Chaer, 2009) mengatakan bahwa kemampuan menggunaakan bunyi bahasa termasuk dari kematangan kognitif, sebab semakin lama kognitif seseorang akan bertambah. Artinya bahwa tingkat intelektual seorang anak menentukan proses pemerolehan bahasa pada anak. Piaget menegaskan lebih jauh bahwa bukanlah lingkungan yang mempengaruhi kemampuan berbahasa yang dengan sendirinya dipelajari, melainkan anaklah yang berperan aktif dalam proses pemerolehan bahasanya. Artinya, lingkunganlah yang pasif dalam proses pemerolehan bahasa si anak.

\section{Tahapan Pemerolehan Fonologi Bahasa}

Secara fonologis, organ anak dengan orang dewasa sangat berbeda. Misalnya, berat otak antara anak-anak dengan dewasa berbeda. Berat otak anak-anak hanya 30\% dari ukuran orang dewasa. Organ yang lain juga memiliki perbedaan yang mencolok, yaitu pada rongga mulut. Jelas terlihat bahwa rongga mulut orang dewasa dengan anak-anak sungguh berbeda. Rongga mulut anak-anak masih dipenuhi oleh selaput, sehingga membuatnya keterbatasan dalam menggerakkannya, berbeda dengan rongga mulut pada orang dewasa. Pada orang dewasa, rongga mulutnya jauh lebih besar sehingga memudahkan dalam mengeluarkan berbagai bunyi bahasa.

Pemerolehan fonologi atau bunyi-bunyi bahasa diawali dengan pemerolehan bunyibunyi dasar. Bunyi-bunyi dasar yang belum melibatkan bagian lidah secara aktif, disebabkan luas rongga mulut. Menurut Jakobson bunyi dasar tersebut adalah bunyi bilabial dan bebrapa bunyi vokal $[\mathrm{p}],[\mathrm{a}],[\mathrm{i}],[\mathrm{u}],[\mathrm{t}],[\mathrm{c}],[\mathrm{m}]$, dan seterusnya, dengan berkembang organorgannya, baik pada biologi maupun neurologi. Kemudian pada usia satu tahun anak mulai mengisi bunyi-bunyi tersebut dengan bunyi lainnya. Misalnya [p] dikombinasikan dengan [a] menjadi pa/ dan /m/ dikombunisakan dengan [a] menjadi [ma]. Sering dengan kemampuan anak, kemampuan untuk mengucapkan bunyi akan terus bertambah sampai anak mahir dalam berbahasa.

Menurut Arifuddin (2010: 153-155), tahap-tahap pemerolehan bahasa anak secara universal terbagi menjadi empat tahap, yaitu praujaran, meraban, tahap satu kata, dan tahap penggabungan kata.

\section{a) Tahap Praujaran (pre-speech)}


Sebelum anak mampu mengucapkan bunyi-bunyi fonem pembentuk makna, anak dalam berkomunikasi masih menggunakan intonasi atau bunyi yang tak bermakna. Bayi memberikan tanggapan terhadap bahasa (ujaran) lebih cermat dibandingkan dengan bunyi-bunyi lainnya. Akan tetapi, anak tidak belajar bagaimana menggunakan bunyi tersebut sampai beberapa lama kemudian. Menurut Mar'at (dalam Arifuddin, 2010: 153), pada tahap ini perkembangan yang terlihat jelas adalah perkembangan kognisinya. Artinya bahwa anak berusaha memahami apa yang diujarkan oleh orang dewasa melalui gerak refleks, seperti rasa lapar, respon terhadap cahaya dengan mengedipkan mata, dan lain-lain. pada tahap ini berlangsung sampai usia 1 tahun.

b) Tahap Meraban/Berceloteh

Pada tahap ini ditandai dengan celotehan si anak yang berupa bunyi-bunyi yang masih belum bisa diidentifikasi bentuknya. Dalam artian bahwa, apakah bunyi tersebut bunyi vokal atau konsonan. Bunyi-bunyi yang keluar itu tidak menandakan ujaran dalam bahasa yang digunakan oleh anak, dalam hal ini bahasa ibunya. Hal ini disebabkan oleh kesukaran dalam pelafalan serta belum jelasnya satuan konsonan ataupun pengulangan pengulangan suku kata.

c) Tahap Satu Kata

Tahap ini ditandai dengan munculnya lambang bahasa yang sudah bisa diidentifikasi, baik itu bunyi vokal maupun bunyi konsonan, dengan menyederhanakannya. Dalam bahasa Indonesia, tahap ini masih sulit mengucapkan kata rambut, lubang, dan sebagainya. Pada tahap ini juga anak sudah bisa meghasilkan lima puluh kata pertamanya, biasanya berupa nama orang, makanan, kegiatan sehari-hari dan sapaan.

d) Tahap Banyak Kata

Pada tahap ini anak sudah mampu berkomunikasi walaupun masih belum mahir sebagaimana orang dewasa. Tahap ini terjadi menjelang usia 2,5 tahun. Pada usia inilah anak sudah mampu mengucapkan banyak kata. Menjelang betambahnya usia dan tentunya berkembangnya organ bahasa anak, secara biologi dan neurologi, anak akan mampu berkomunikasi seperti orang dewasa dan tidak lagi menggunakan hanya satu kata.

\section{Perkembangan Ujaran}

Pemerolehan bahasa anak berkaitan erat dengan konsep universal. Karena anak dapat memperoleh bahasa apapun yang disajikan kepadanya. Dalam konsep universal dengan pemerolehan fonologi, sejauh ini yang banyak digunakan adalah pendapat Roman Jakobson. Dia berpendapat bahwa dalam pemerolehan bunyi fonem terjadi secara teratur mengikuti kodrat bahasa itu sendiri. Artinya, bunyi yang keluar adalah perpaduan bunyi konsonan dan bunyi vokal. Dalam hal vokal, hanya bunyi [a], [i], dan [u] yang keluar terlebih dahulu. Dari tiga bunyi ini, [a] akan keluar lebih dulu daripada [i] atau [u], karena bunyi fonem tersebut dikenal dengan Sistem Vokal Minimum (dalam Dardjowidjojo, 2016).

Mengenai konsonan Jakobson (dalam Dardjowidjojo, 2016) mengatakan bahwa bunyi yang pertama mampu diucapkan anak adalah bunyi oral dengan bunyi nasal ([p-b] dan [mn]) dan kemudian disusul oleh bunyi bilabial dengan dental ([p]-[t]). Sistem ini oleh jakobson dinamai dengan Sistem Konsonan Minimal.

Urutan dalam pemerolehan bunyi-bunyi fonem tidak terlepas dari pengaruh aspek biologi dan neorologi, dan kemunculan bunyi-bunyi tersebut antara anak yang satu dengan anak yang lain tidaklah sama, sebab setiap anak mengalami perkembangan biologi dan neurologi yang tidak sama pula. Oleh kerena itu, tidak bisa kita menyamaratkan proses pemerolehan bahasa atau perkembangan ujaran anak dari jumlah usia.

\section{METODE PENELITIAN}


Pendekatan yang digunakan dalam penelitian ini adalah pendekatan deskriptif kualitatif. Pendekatan ini mencoba menggambarkan dan memahami sesuatu terkait fenomena yang akan diteliti berdasarkan perspektif peneliti. Secara harfiah, penelitian dengan pendekatan deskriptif adalah penelitian yang bermaksud untuk membuat pencandraan (deskripsi) mengenai situasi atau kejadian-kejadian, dalam hal ini tuturan bahasa. Tuturan bahasa yang didapatkan dari objek penelitian nantinya akan dijelaskan berdasarkan perspektif peneliti berdasarkan data yang didapatkan (dalam Suryabrata, 2006). Penelitian kualitatif dilakukan pada objek yang alamiah. Artinya bahwa objek berkembang apa adanya tanpa dimanipulasi oleh peneliti. Dengan kata lain, dalam penelitian kualitatif tidak menekankan pada generalisasi (penyamarataan), tetapi menekankan pada makna, dan biasanya peneliti itu sendiri sebagai instrumennya (Sugiyono, 2015).

Data dalam penelitian ini adalah ujaran yang keluar dari Rasyid yang berupa katakata yang kemudian akan diolah dan dianalisis. Sedangkan sumber data dalam penelitian ini adalah subjek penelitian itu sendiri, yaituRasyid Hidayat. Berikut biodata dari subjek penelitian.

Nama : Rasyid Hidayat

Tempat, tanggal lahir : Kelebuh, 4 Mei 2016

Alamat : Dusun Kelebuh, Desa Kelebuh, Kecamatan Praya Tengah, Kabupaten Lombok Tengah.

Metode pengumpulan data yang digunakan dalam penelitian ini adalah metode simak teknik sadap dengan teknik lanjutan yaitu teknik libat cakap. Hal ini peneliti bermaksud melakukan penyadapan dengan cara ikut berpartisipasi sambil menyimak, berpartisipasi dalam pembicaraan, dan menyimak pembicaraan. Metode simak teknik sadap dilakukan dengan teknik lanjutan yang lain yaitu teknik catat dan teknik rekam. Metode selanjutnya adalah metode cakap teknik pancing. Metode cakap dengan teknik pancing dilakukan dengan memberi stimulus (pancingan) pada informan untuk memunculkan gejala kebahasaan yang diharapkan oleh peneliti (Mahsun, 2014).

Teknik analisis data yang dilakukan dalam penelitian ini mengacu pada kajian analisis deskripsif kualitatif. Nurastuti (dalam Trinowismanto, 2016) menjelaskan analisis deskriptif kualitatif yang dimaksud adalah analisis dengan merinci dan menjelaskan secara panjang lebar keterkaitan data penelitian dalam bentuk kalimat. Dardjowidjojo (2000) menjelaskan bahwa ada dua aspek dalam menganalisis data. Pertama, data dianalisis untuk mencari tahu elemen-elemen fonem, morfologi dan seterusnya, mana yang muncul pada kurun waktu tertentu. Kedua, setelah data dianalisis dan disajikan secara deskriptif dengan menyoroti hasil atau data tersebut dengan kajian berbagai segi teoretis. Analisis data dalam penelitian menggunakan empat langkah, (1) tahap klasifikasi, (2) tahap identifikasi, (2) tahap interpretasi, dan (4) tahap deskripsi. Data yang dianalisis adalah data yang sudah ditranskip dalam bentuk kata-kata dari ujaran yang sudah direkam, baik audio maupun audio-visual.

Penyajian hasil analisis data dalam penelitian kualitatif ini yaitu secara informal dan formal. Penyajian hasil analisis data secara informal yaitu dengan menggunakan kata-kata biasa. Dalam artian bahwa kata-kata yang dibaca serta merta dapat dipahami dengan mudah oleh pembaca walaupun disertakan tanda baca atau lambang yang berupa singkatan. Hal ini dimaksudkan untuk menghindari kesalah-mengartikan. Penyajian hasil analisis data secara formal sendiri dengan menggunakan kaidah, baik berupa pelafalan atau lambang dan tabel. $\mathrm{Hal}$ ini untuk memberikan gambaran atau penjelasan secara rinci terkait hasil analisis data agar mudah dipahami oleh pembaca (dalam Kesuma, 2007). Selain itu, penyajian hasil analisis data dalam penelitian ini menggunakan pendekatan induktif dan deduktif. 
Pendekatan induktif dan deduktif dimaksudkan supaya penyajian hasil analisis data tidak monoton.

\section{PEMBAHASAN}

Penelitian ini menguraikan tentang bentuk pemerolehan fonem bahasa ibu pada anak usia 2,6 tahun yaang merupakan studi kasus pada Rasyid Hidayat.

\section{Pemerolehan Fonem Bahasa Ibu Anak Usia 2,6 Tahun}

Pemerolehan fonologi merupakan pemerolehan bunyi-bunyi dalam bahasa. Pemerolehan fonologi ini berkaitan dengan kemampuan anak dalam mengucapkan lambang-lambang bunyi tersebut, baik vokal, semi vokal, dan konsonan. Setiap anak pasti mengalami atau melalui proses pemerolehan bahasa pada aspek fonologi tersebut. Terlihat ketika anak lahir belum mampu mengucapkan bunyi bahasa sebagaimana orang dewasa. Dengan berjalannya waktu dan bertambahnya usia serta kesiapan neurobiologis, fonem satu dengan fonem yang lain mulai dikuasai dan mampu diujarkan oleh anak, sebagaimana yang terjadi pada subjek penelitian ini, yaitu Rasyid Hidayat.

Perkembangan pemerolehan bahasa pada anak, sebagaimana yang telah dijelaskan sebelum-sebelumnya, bahwa kita tidak bisa menjadikan kalender kelahiran menjadi satusatunya patokan terkait dengan pemerolehan bahasa. Perlu dipahami bahwa perkembangan pemerolehan bahasa anak, kesiapan aspek neurobiologisnya perlu dijadikan sebagai patokan perkembangan bahasa pada anak. Sebab, ada anak yang cepat dan ada pula yang lambat dalam pemerolehan bahasanya. Anak yang usianya lebih muda mungkin mengalami pemerolehan yang lebih cepat dibandingkan dengan anak yang usianya lebih tua. Akan tetapi, rujukan ke jumlah tahun dan bulan memang lebih mudah sehingga cara itulah yang umumnya dipakai oleh orang.

a. Pemerolehan Fonem Vokal

Pemerolehan fonem vokal merupakan pemerolehan fonem bahasa tanpa ada proses hambatan dalam artikulasinya. Artinya bahwa, pengucapan dari fonem vokal tersebut terjadi ketika udara yang dihirup kemudian dihembuskan tanpa ada hambatan dari alat-alat bicara baik secara oral maupun nasal. Sebagaimana anak pada umumnya, pemerolehan fonem vokal ini juga terjadi pada Rasyid. Pada usia 2,6 tahun, Rasyid sudah mampu menguasai semua fonem vokal. Pemerolehan fonem vokal, yang paling dulu dikuasi adalah vokal/a/, /i/, dan /u/. Ketiga vokal ini ada di semua bahasa dan oleh karena itu vokal ini disebut Sistem Vokal Minimum. Adapun fonem vokal yang sudah dikuasai adalah/a/,/i/,/u/,/e/,/o/.

Berikut data ujaran pemerolehan fonem vokal pada Rasyid Hidayat.

Tabel 1

Data Ujaran Pemerolehan Fonem Vokal Usia 2,6 Tahun

\begin{tabular}{|c|c|c|c|c|}
\hline No. & Fonem Vokal & Kata & Ujaran & Arti \\
\hline \multirow[t]{2}{*}{1.} & \multirow[t]{2}{*}{$/ a /$} & latas/ & [atas] & Atas \\
\hline & & /amaq/ & [ama?] & Ayah \\
\hline \multirow[t]{2}{*}{2.} & \multirow[t]{2}{*}{ /i/ } & /inaq/ & [ina?] & Ibu \\
\hline & & /mandiq/ & [andi?] & mandi \\
\hline \multirow[t]{2}{*}{3.} & \multirow[t]{2}{*}{$/ \mathrm{u} /$} & /sugul/ & [UdUn] & Keluar \\
\hline & & lakul & [atu] & Saya \\
\hline \multirow[t]{2}{*}{4.} & \multirow[t]{2}{*}{ le/ } & /entun/ & [ontUn] & Turun \\
\hline & & /tame/ & [amə] & Masuk \\
\hline \multirow[t]{2}{*}{5.} & \multirow[t]{2}{*}{ /o/ } & loleq/ & [ow $\varepsilon ?]$ & Pulang \\
\hline & & /poloq/ & [owo?] & Taruh \\
\hline
\end{tabular}


Perkembangan pemerolehan fonem vokal pada Rasyid secara konsisten dikuasai. Fonem-fonem vokal ini mampu diucapkan pada setiap kata yang keluar. Hal ini menandakan tingkat penguasaan pengucapan fonem-fonem vokal. Misalnya pada bunyi vokal /a/, sudah bisa diucapkan di setiap kata yang mengandung vokal /a/.

Pada data (1) tabel 1 di atas menunjukkan bahwa pengucapan fonem vokal /a/ sudah mampu diucapkan. Dilihat dari posisi fonem tersebut bahwa vokal /a/ berada pada posisi awal ujaran tersebut, walaupun huruf pertama kata tersebut adalah /s/ yaitu pada kata /atas/ [atas] 'atas'. Untuk fonem konsonan yang hadir pada setiap fonem vokal akan dibicarakan pada bagian tersendiri yaitu pemerolehan fonem konsonan, sehingga fokus pada pemerolehan fonem vokal.

Pada data (2) yaitu kata /inaq/ [ina?] 'ibu' di atas menunjukkan bahwa penguasaan fonem-fonem vokal tidak hanya pada bunyi /a/ saja, tetapi fonem /i/ juga sudah mampu diucapkannya. Dari data tersebut terlihat bahwa fonem vokal /i/ sudah mampu diucapkannya pada posisi awal ujaran. Kata tersebut sudah mampu diucapkannya dengan utuh sebagaimana pada kata /amaq/ [ama?] 'ayah'.

Pada table nomor 3 tersebut menunjukkan bahwa fonem vokal/u/ sudah mampu diujarkan pada posisi awal dan tengah ujaran. Kata tersebut masih belum utuh diucapkannya. Penguasaan fonem vokal / $\mathrm{u} /$ pada posisi awal juga bisa dilihat padakata /uwah/ [uwah] 'sudah'. Fonem vokal /u/ tidak hanya terdapat pada awal dan tengah ujaran tetapi terdapat juga pada akhir ujaran. Hal ini dapat dilihat pada kata /aku/ [atu] 'saya'.

Fonem vokal /e/ juga sudah mampu dikuasai atau hadir pada /entun/ [əntUn] 'turun'. kata /oleq/ [owe?] 'pulang'. Fonem vokal/e/ sudah mampu diucapkan pada posisi akhir ujaran seperti yang dilihat pada kata/tame/ [amə] 'masuk' tabel tersebut. Tidak hanya itu, fonem /o/ juga sudah mampu diucapkannya. Hal ini bisa dilihat pada tabel 1 yaitu kata/oleq/ [owe?] 'pulang' dan kata/poloq/ [owo?] 'taruh

Dari data di atas terlihat bahwa Rasyid sudah mampu mengucapkan semua jenis fonem vokal. Fonem-fonem vokal yang sudah dikuasai tidak terlepas dari kesiapan organ wicara. Dengan bertambahnya usia, maka organ wicara dari Rasyid juga akan semakin matang, sebab sejak baru lahir mulut anak dipenuhi oleh lidah. Mulut yang masih dipenuhi oleh lidah ini membuat gerakan-gerakan refleks yang belum bisa dipastikan apakah itu bentuk fonem atau tidak. Karena fonem-fonem vokal dihasilkan dari gerakan-gerakan lidah - tinggi rendahnya lidah dan bagian lidah yang bergerak. Apabila dilihat dari proses artikulasi pada alat wicara, bahwa bunyi vokal terjadi karena tidak ada hambatan pada alat wicara. Hambatan hanya terjadi pada pita suara. Dengan demikian, pada usia 2,6 tahun Rasyid sudah mampu dalam mengucapkan fonem-fonem vokal tanpa ada kekeliruan atau hambatan.

Penguasaan atau pemerolehan semua jenis fonem vokal pada Rasyid sudah terjadi pada usia 2,2 tahun. Pada usia tersebut bisa dikatakan bahwa pengucapan atau pelafalan fonem vokal sudah tidak ada lagi kesalahan atau kekeliruan. Semua kata yang mengandung fonem vokal sudah mampu diucapkannya. Misalnya pada kata /entun/ 'turun' diucapkan [əntUn], atau pada kata /sawut/ 'lempar' diucapkan [awUt]. Hal ini menunjukkan perkembangan atau kemampuan Rasyid dalam mengucapkan fonem vokal tersebut. Oleh karena itu, Rasyid sudah mampu mengucapkan semua jenis fonem vokal pada usia 2,6 tahun bahkan kemampuan mengucapkan semua jenis fonem vokal sudah terjadi pada usia 2,2 tahun.

Pemerolehan bunyi vokal Rasyid pada usia 2,6 tahun bisa digambarkan dengan bagan di bawah ini.

Bagan pemerolehan bunyi vokal 


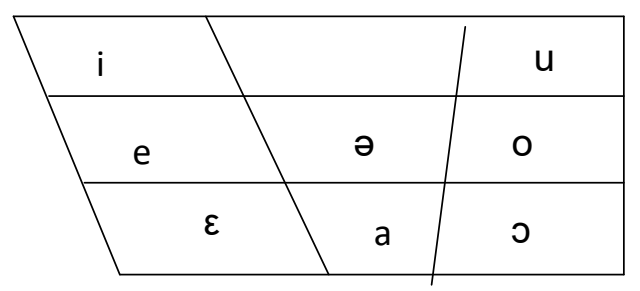

b. Pemerolehan Fonem Konsonan

Pada bagian sebelumnya sudah dijelaskan terkait pemerolehan fonem vokal, maka pada bagian ini akan dibahas secara khusus mengenai pemerolehan fonem konsonan. Pemerolehan fonem konsonan merupakan pemerolehan bunyi-bunyi yang terjadi karena adanya hambatan pada alat wicara. Dalam artian bahwa, ketika udara masuk ke dalam paru-paru kemudian udara itu dihembuskan, dan bersamaan dengan hembusan udara itu terjadi hambatan pada alat wicara.

Pemerolehan fonem konsonan merupakan pemerolehan bunyi-bunyi yang terjadi karena adanya hambatan pada alat wicara. Dalam artian bahwa, ketika udara masuk ke dalam paru-paru kemudian udara itu dihembuskan, dan bersamaan dengan hembusan udara itu terjadi hambatan pada alat wicara. Pada usia 2,6 tahun Rasyid sudah mampu mengucapkan berbagai bentuk fonem konsonan. Adapun fonem konsonan yang sudah dikuasai oleh Rasyid adalah /p/, /b/, /d/, /m/, /n/, /t/, /h/, /c/, /s/, /w/, /y/, /q/, dan /k/. Kedua fonem terakhir ini belum sempurna diucapkan oleh Rasyid, dan terdapat pada akhir kata yang menyerupai bunyi glotal. Pada tengah kata konsonan /k/ diganti dengan fonem /t/, misalnya kata /aku/ yang diucap [atu].

Berikut data ujaran pemerolehan fonem konsonan pada Rasyid Hidayat.

Tabel 2

Data Ujaran Pemerolehan Fonem Konsonan 2,6 Tahun

\begin{tabular}{|c|c|c|c|c|}
\hline No. & Fonem Konsonan & Kata & Ujaran & Arti \\
\hline \multirow[t]{2}{*}{1.} & \multirow{2}{*}{$/ \mathrm{p} /$} & /ampaq/ & [ampa?] & 'jalan’ \\
\hline & & lempaq/ & [әтра?] & 'ikan’ \\
\hline \multirow[t]{2}{*}{2.} & \multirow[t]{2}{*}{ /b/ } & /ban/ & [ban] & 'roda' \\
\hline & & /sabo/ & [abo] & ‘sawo’ \\
\hline \multirow[t]{2}{*}{3.} & \multirow[t]{2}{*}{$\mid t /$} & /tutup/ & [tUtUt] & 'tutup' \\
\hline & & /anget/ & [anot] & 'hangat \\
\hline \multirow[t]{2}{*}{4.} & \multirow[t]{2}{*}{$/ \mathrm{d} /$} & /endah/ & [endah] & 'juga' \\
\hline & & /adoh/ & [doh] & 'aduh’ \\
\hline \multirow[t]{2}{*}{5.} & \multirow[t]{2}{*}{$/ \mathrm{m} /$} & /nyupir/ & [nupIm] & 'menyopir' \\
\hline & & /mah/ & [mah] & ‘ini’ \\
\hline \multirow[t]{2}{*}{6.} & \multirow[t]{2}{*}{$/ \mathrm{n} /$} & /aneh/ & [aneh] & 'ayo' \\
\hline & & /bulan/ & [uwan] & 'bulan' \\
\hline \multirow[t]{2}{*}{7.} & \multirow[t]{2}{*}{ /h/ } & /masih/ & [acih] & 'masih' \\
\hline & & /bareh/ & [ayeh] & 'nanti' \\
\hline \multirow[t]{2}{*}{8.} & \multirow[t]{2}{*}{$/ \mathrm{s} /$} & /atas/ & [atas] & 'atas' \\
\hline & & /panas/ & [anas] & 'panas' \\
\hline 9. & $/ \mathrm{c} /$ & /cas/ & [cas] & 'cas' \\
\hline \multirow[t]{2}{*}{10.} & \multirow[t]{2}{*}{$/ \mathrm{w} /$} & /tuwaq/ & [uwa?] & 'paman' \\
\hline & & lowat/ & [owat] & 'obat' \\
\hline \multirow[t]{2}{*}{11.} & \multirow[t]{2}{*}{$/ \mathrm{y} /$} & lyaq/ & [ya?] & 'mau' \\
\hline & & /sembayang/ & [aya] & 'salat' \\
\hline \multirow[t]{2}{*}{12.} & \multirow[t]{2}{*}{$/ q /$} & /papuq/ & [apu?] & 'nenek' \\
\hline & & baloq/ & [awo?] & 'buyut' \\
\hline 13. & $/ \mathrm{k} /$ & /bobok/ & [bobo?] & 'tidur' \\
\hline
\end{tabular}




\begin{tabular}{rcc} 
/manok/ & [nano?] & 'ayam' \\
\hline Keterangan: Data dalam ujaran Bahasa Sasak &
\end{tabular}

Pada pemerolehan fonem-fonem konsonan, urutan universal yang dianut anak pada umumnya berlaku pula pada Rasyid. Pada kelompok konsonan hambat, misalnya, konsonan bilabial /p-t/ dan nasal /m-n/muncul lebih dahulu dan secara teratur.

Fonem konsonan /p/ sudah mampu diucapkan. Hal ini bisa dilihat pada kata /lampaq/ [ampa?] 'jalan' dan kata /empaq/ [ompa?] 'ikan'. Kedua kata tersebut menunjukkan bahwa Rasyid sudah mampu mengucapkan fonem konsonan bilabial/p/. Hadirnya fonem bilabial ini terdapat pada posisi tengah ujaran. Fonem /b/ juga juga sudah mampu dia ucapkan. Hal ini bisa dilihat pada kata /ban/ [ban] 'ban' dan kata/sabo/ [abo] 'sawo'.

Terlihat pada data di atas kemampuan Rasyid dalam mengucapkan fonem konsonan /t/ pada semua posisi. Misalnya, pada posisi awal terlihat pada kata / tutup/ [tUtUt] 'tutup'. Kata tersebut terdapat juga di posisi tengah dan akhir ujaran. Pada posisi tengah dapat terlihat pada kata /entun/ [əntUn] 'turun', dan kata /atas/ [atas] 'atas'. Sedangkan pada posisi akhir dapat dilihat pada kata /anget/ [anət] 'hangat'.

Data di atas menjelaskan bahwa pada usia 2,6 tahun Rasyid sudah mampu mengucapkan fonem konsonan /d/. Kemampuan dalam mengucapkan fonem konsonan tersebut hadir pada posisi awal dan tengah kata atau ujaran. Misalnya, pada posisi awal kata atau ujaran terdapat pada kata /adoh/ [doh] 'aduh'. Pada kata tersebut fonem /d/ diujarkan pertama kali olehnya dan menduduki awal ujaran. Pada posisi tengah terdapat pada kata /endah/ [endah] 'juga', /mandiq/ [andi?] 'mandi', dan kata /sepedah/ [edah] 'sepeda'. Pada posisi akhir sendiri fonem ini belum terdengar dalam kata atau ujaran.

Pada data di atas terlihat kemampuan Rasyid dalam mengucapkan fonem nasal /m/ dan /n/, yaitu pada kata / mah/ [mah] 'ini' dan kata /aneh/ [aneh] 'ayo'. Tidak hanya fonem $/ \mathrm{m} /$ dan $/ \mathrm{n} /$ yang sudah terlihat, fonem konsonan $/ \mathrm{h} /$ hanya ada pada posisi akhir kata atau ujaran. Pada posisi akhir terdapat juga pada kata /endah/ [endah] 'juga', /adoh/ [doh] 'aduh', /mah/ [mah] 'ini', /aneh/ [aneh] 'ayo'.

Pada usia 2,1 tahun fonem frikatif /s/ belum muncul dan belum mampu untuk diucapkan pada semua posisi. Misalnya pada kata /atas/ [atah] 'atas' dan pada kata /pedis/ [dIh] 'kecut'. Pada kata tersebut, fonem /s/ mengalami penggantian fonem konsonan /h/ di akhir kata. Dengan bertambahnya usia dan berkembangnya aspek biologis, pada usia 2,6 tahun sudah mulai muncul dan mampu diucapkan, tetapi pada akhir kata atau ujaran seperti pada kata /atas/ [atas] 'atas', /panas/ [anas] 'panas'. Sedangkan pada tengah kata masih diganti dengan fonem konsonan yang lain, yaitu fonem konsonan /c/.

Fonem konsonan afrikatif ringan /c/ sudah mampu diucapkannya seperti pada kata/cas/ [cas] 'cas'. Fonem konsonan /c/ pernah muncul ketika bunyi ini menggantikan bunyi konsonan /s/ pada tengah kata, yaitu pada kata/nasiq/ [aci?] 'nasi', kata /masih/ [acih] 'masih', dan kata/rasyid/ [rasyid] 'rasyid'. Sedangkan untuk padanan beratnya /j/ masih belum mampu diucapkan dan sering muncul sebagai /d/, misalnya pada kata/jaje/ 'jajan' yang diucapkan seperti bunyi /d/ yaitu [dade] atau pada kata /ngaji/ 'mengaji' diucapkan [adi].

Pada usia 2,6 tahun Rasyid sudah mampu mengucapkan fonem semi konsonan /w/ dan/y/ seperti pada kata/tuwaq/ [uwa?] 'paman', /lawang/ [awa] 'pintu', dan pada kata /sembayang/ [aya] 'salat'. Fonem semi konsonan /w/ sudah hadir pada posisi awal dan tengah ujaran atau kata. Begitupun fonem semi konsonan /y/ sudah terdengar pada awal dan tengah ujaran atau kata, seperti pada/yaq/ [ya?] 'mau'. Pada akhir kata atau ujaran, 
kedua fonem ini belum terdengar. Hal ini juga dikarenakan kosakata yang mengandung konsonan pada akhir kata terbatas bahkan belum ditemukan.

Dari data di atas terlihat bahwa pada usia 2,6 tahun Rasyid sudah mampu mengucapkan berbagai bentuk fonem konsonan. Fonem-fonem konsonan, sebagaimana yang terdapat pada data tersebut bahwa masih belum menduduki semua posisi dalam setiap kata yang diujarkannya. Ada fonem konsonan yang hanya terdapat pada awal kata; ada pada awal dan tengah kata; ada pula pada akhir kata saja, atau pada semua posisi tersebut. Dan untuk fonem konsonan yang belum mampu diucapkan mengalami pergantian dengan fonem yang lain.

Di samping fonem-fonem vokal maupun konsonan yang sudah dikuasai, bunyibunyi diftong juga sudah dikuasainya. Tidak hanya diftong $[\mathrm{a}-\mathrm{i}]$ yang sudah dia kuasai seperti pada kata maiq 'enak', bait 'ambil', tetapi diftong [u-i] pada kata uik 'kemarin', [ao] pada kata maong 'kucing' juga sudah dia kuasai.

Fonem konsonan bilabial /p/, /b/ dan nasal /m/, /n/ sudah dikuasai dengan baik oleh Rasyid, tetapi apabila konsonan tersebut berada di awal kata sering dihilangkan dan didominasi oleh fonem vokal. Fenomena tersebut sering terjadi, sebab ini merupakan bentuk dari penyederhanaan dari kanak-kanak. Penyederhanaan ini disebabkan oleh faktor kesiapan aspek atau organ bicara atau posisi suatu fonem ketika diucapkan. Misalnya dalam kata /sembayang/, dia mengucapkan [aya] 'salat' yang merupakan bentuk penyederhanaan. Atau pada contoh yang lain yaitu kata/montor/, dia mengucapkan [ton]/[onton] 'motor'. Terkait dengan fenomena ini, Ingram menjelaskan perkembangan ini melalui asimilasi dan akomodasi yang terus menerus sampai kematangan aspek neurobiologi sehingga anak mampu mengucapakan sebagaimana orang dewasa.

Mengacu pada teori perkembangan fonologi pada anak yang disampaikan oleh Jakobson, bahwa konsonan hambat lebih dulu dikuasai daripada konsonan frikatif dan afrikatif menunjukkan hal yang menarik. Perkembangan fonologi bahasa pertama pada Rasyid mengikuti teori universal yang dinyatakan Jakobson, meskipun tidak sepenuhnya. Hal menarik dapat dilihat pada tabel 3 pemerolehan fonem konsonan usia 2,6 tahun.

Tabel 4.4

Fonem Konsonan Usia 2,2 Tahun

\begin{tabular}{|c|c|c|c|c|c|c|}
\hline $\begin{array}{c}\text { Titik/cara } \\
\text { artikulasi }\end{array}$ & Bilabial & $\begin{array}{c}\text { Labio- } \\
\text { dental }\end{array}$ & Alveolar & $\begin{array}{c}\text { Alveo- } \\
\text { palatal }\end{array}$ & Velar & Glotal \\
\hline Hambat & $\mathrm{p}$ & $\mathrm{t}$ & & & $\begin{array}{c}q \\
k\end{array}$ & $?$ \\
\hline Frikatif & $\mathrm{d}$ & & $\mathrm{s}$ & & & $\mathrm{h}$ \\
\hline Afrikatif & & & & $\mathrm{c}$ & & \\
\hline Nasal & $\mathrm{m}$ & & $\mathrm{n}$ & & & \\
\hline Semivokal & $\mathrm{w}$ & & & $\mathrm{y}$ & & \\
\hline
\end{tabular}

Catatan: untuk yang bercetak miring muncul secara terbatas dan berada di akhir kata yang menyerupai bunyiglotal.

Konsonan velar /k/ dan /g/ belum terdengar kecuali /k/ pada akhir kata yang menyerupai bunyi glotal. Fonem konsonan velar/g/ belum mampu diucapkan dan diganti dengan fonem konsonan /d/ seperti pada kata/sugul/ [UdUn] 'keluar'.

Untuk bunyi nasal alveo-palatal / $\tilde{n} /$ dan bunyi nasal velar / $\mathrm{y} /$ masih diucapkan sebagai /n/ sampai pada usia 2,6 tahun, seperti kata /anget/ [anət] 'hangat" dan kata /nyupir/

[nupIm] 'menyopir'. Pada usia 2,6 tahun juga, fonem konsonan /f/ dan /v/ 
masih belum dikuasai. Fonem konsonan /f/ dalam pelafalan orang Sasak sering mengucapkan dengan bunyi konsonan /p/. Begitu pula dengan konem konsonan /z/ belum mampu diucapkan dan diganti dengan fonem /d/ pada kata /azan/ [ada] 'azan' (nama teman bermainnya). Fonem lateral /1/ dan getar /1/ belum mampu diucapkan dan diganti dengan fonem $/ \mathrm{m} /$ atau $/ \mathrm{n} /$ pada akhir kata, sedangkan pada tengah kata diganti dengan fonem $/ \mathrm{y} / \mathrm{atau} / \mathrm{w} /$.

c. Perkembangan Kinesik dan Komprehensi

Peneliti merasa perlu untuk memaparkan perkembangan kinesik dan komprehensi Rasyid Hidayat pada usia 2,2 tahun. Sebab, bersama perkembangan pemerolehan bahasa pertama pada tidak terlepas dari perkembangan neurobiologisnya. Kesiapan mental maupun kesiapan biologis dalam mengucapkan fonem-fonem akan berdampak pada perkembangan pemerolehan bahasa pertamanya. Oleh karena itu, tidak ada salahnya peneliti memaparkan sedikit terkait dengan perkembangan kinesik dan komprehensinya.

Perkembangan kinesik ini berkaitan dengan kemampuan gerak fisik pada anak tersebut. Pada usia 2,6 tahun, perkembangan kinesik Rasyid sudah tidak lagi terjatuhjatuh. Gerakan motoriknya sudah mampu menyesuaikan dengan kondisi lingkungan. Hal ini terlihat ketika Rasyid bermain mobil-mobilan atau menunggang sepeda. Perkembangan komprehensi sendiri berkaitan dengan masukan dari luar. Masukan dari luar ini memberikan model pada anak dalam memproduksi bahasa. Begitupun Rasyid pada usia 2,6 tahun, kemampuan komprehensinya semakin berkembang. Kemampuan memahami ujaran oleh anak lebih dulu dipahami sebelum anak mampu mengujarkan bunyi atau kata tersebut. Kemampuan memahami ujaran dan kemampuan mengucapkan bunyi-bunyi bahasa terus berkembang walaupun pada usia 2,6 tahun ia belum terlalu lengkap mengucapkan kata-kata sebagaimana orang dewasa.

\section{Bahasan Fonem Anak Usia 2,6 Tahun}

Neurobiologis Rasyid yang terus berkembang memungkinkan dia untuk mampu mengucapkan fonem-fonem yang lain dalam bentuk suku kata, kata, bahkan kalimat, walaupun pada usia 2,6 tahun belum seperti ujaran orang dewasa. Neurobiologinya akan terus berkembang sampai dia mampu berujar layaknya orang dewasa.

Pada usia 2,6 tahun, fonem-fonem konsonan yang belum dikuasai diganti dengan konsonan yang sudah dikuasainya. Penggantian fonem konsonan ini tidak terjadi secara acak, tetapi melalui suatu pola atau strategi yang konsisten. Penggantian bunyi konsonan yang satu dengan bunyi konsonan yang lain juga berdasarkan kedekatan artikulasi atau urutan pemerolehan fonem.

Di usianya yang 2,6 tahun ini Rasyid sudah membuat strukturnya sendiri dalam melakukan komunikasi dengan orang di sekitarnya. Struktur maupun pola yang sudah dibentuknya secara konsisten dilakukan dalam mengujarkan suatu kata. Adapun pola atau strategi yang sudah dibentuk oleh Rasyid dalam pemerolehan fonem bahasa ibu pada usia 2,2 tahun sebagai berikut.

a. Konsonan $/ \mathrm{k} / \rightarrow$ konsonan $/ \mathrm{t} /$ pada tengah kata dan glotal stop pada akhir kata.

$$
\begin{aligned}
& \text { laku/ } \rightarrow \text { [atu] 'aku' } \\
& \text { /manok/ } \rightarrow \text { [nano?] 'ayam' }
\end{aligned}
$$

b. Konsonan /g/dan konsonan /z/ $\rightarrow$ konsonan /d/ pada tengah kata.

/sugul/ $\rightarrow$ [UdUn] 'keluar'

lazan/ $\rightarrow$ [ada] 'azan' 
c. Konsonan $/ \mathrm{s} / \rightarrow$ konsonan /c/ pada tengah kata, dan pada akhir kata tetap.

/masih/ $\rightarrow$ [acih] 'masih'

/panas/ $\rightarrow$ [anas] 'panas'

d. konsonan $/ \tilde{\mathrm{n}} /$ dan konsonan $/ \mathrm{n} / \rightarrow$ konsonan $/ \mathrm{n} /$.

/nyupir/ $\rightarrow$ [nupIm] 'menyopir'

lengkah/ $\rightarrow$ [ontah] 'jangan'

e. Fonem konsonan /q/ $\rightarrow$ menyerupai bunyi glotal pada akhir kata.

/inaq/ $\rightarrow$ [ina?] 'ibu'

lamaq/ $\rightarrow$ [ama?] 'bapak'

f. Konsonan lateral $/ \mathrm{l} /$ dan getar $/ \mathrm{r} / \rightarrow$ konsonan $/ \mathrm{m} /$ atau $/ \mathrm{n} /$ pada akhir kata; dan konsonan /w/ atau /y/ pada tengah kata dengan pola.

/nyupir/ $\rightarrow$ [nupIm] 'menyopir'

/montor/ $\rightarrow$ [ton] 'montor'

1) Pola [a:o], [u:a], [o:o], dan [o:e] $\rightarrow$ fonem $/ \mathrm{w} /$.

loleq $\rightarrow$ [owe? 'pulang'

/baloq/ $\rightarrow$ [awo?] 'buyut'

/bulan/ $\rightarrow$ [uwan] 'bulan'

/poloq/ $\rightarrow$ [owo?] 'taruh'

2) Pola [a:a], [a:i], [a:e], [e:e], dan [e:i] $\rightarrow$ fonem $/ y /$.

/karing/ $\rightarrow$ [ayin] 'tinggal'

/bale/ $\rightarrow$ [aye] 'rumah'

laraq/ $\rightarrow$ [aya?] 'ada'

/meleq/ $\rightarrow$ [eye?] 'mau'

/salaq/ $\rightarrow$ [aya?] 'salah'

/geling/ $\rightarrow$ [eyIn] 'roda'

Berdasarkan hasil analisis terkait pemerolehan fonem bahasa anak pada anak usia 2,6 tahun yang merupakan studi kasus terhadap Rasyid Hidayat dapat ditarik kesimpulan bahwa pada usia 2,6 tahun Rasyid sudah menguasai dengan baik semua fonem vokal, yaitu /a/, /i/, /u/, /e/, dan /o/ dalam setiap kata. Fonem-fonem vokal tersebut hadir di setiap posisi, baik awal, tengah, dan akhir sebuah kata. Tidak hanya fonem vokal yang sudah dikuasai oleh Rasyid, tetapi fonem konsonan juga sudah dikuasai. Fonem konsonan yang sudah dikuasai dan belum semuanya menduduki semua posisi oleh Rasyid pada usia 2,6 tahun yaitu adalah /p/, /b/,/m/,/n/,/t/,/h/,/s/,/c/,/w/,/y/,/q/, dan /k/.

Dalam proses pemerolehan fonem bahasa ibu, Rasyid membuat pola atau aturan sendiri terkait pemerolehan fonem bahasa ibu pada pada usi a 2,6 tahun, sebagai berikut.

a. Konsonan $/ \mathrm{k} / \rightarrow$ konsonan $/ \mathrm{t} /$ pada tengah kata dan glotal stop pada akhir kata.

b. Konsonan /g/dan konsonan /z/ $\rightarrow$ konsonan /d/ pada tengah kata.

c. Konsonan $/ \mathrm{s} / \rightarrow$ konsonan $/ \mathrm{c} /$ pada tengah kata, dan pada akhir kata tetap.

d. Konsonan $/ \tilde{\mathrm{n}} /$ dan konsonan $/ \mathrm{y} / \rightarrow$ konsonan $/ \mathrm{n} /$.

e. Fonem konsonan $/ \mathrm{q} / \rightarrow$ menyerupai bunyi glotal pada akhir kata.

f. Konsonan lateral /l/ dan getar $/ \mathrm{r} / \rightarrow$ konsonan $/ \mathrm{m} /$ atau $/ \mathrm{n} /$ pada akhir kata; dan konsonan $/ \mathrm{w} /$ atau $/ \mathrm{y} /$ pada tengah kata dengan pola.

1. Pola [a:o], [u:a], [o:o], dan [o:e] $\rightarrow$ fonem $/ \mathrm{w} /$.

2. Pola [a:a], [a:i], [a:e], [e:e], dan [e:i] $\rightarrow$ fonem $/ y /$.

Penggantian bunyi yang belum mampu diucapkan dengan bunyi yang lain dilakukan secara teratur, bukan terjadi secara acak. Penggantian yang dilakukan dengan bunyi yang memiliki atau berdekatan artikulatornya. Dan untuk bunyi yang terakhir adalah biasanya bunyi $/ \mathrm{l} / \mathrm{dan} / \mathrm{r} /$. 


\section{PENUTUP}

Setiap anak memang akan mengalami proses dalam pemerolehan bahasa pertamanya. Cepat atau lambat, anak akan mampu berkomunikasi menggunakan bahasa layaknya orang dewasa. Terlepas dari adanya keterlambatan dalam proses pemerolehan bahasa. Begitu pun dengan apa yang terjadi pada Rasyid Hidayat. Pada usia 2,6 tahun sudah menunjukkan proses dari pemerolehan bahasa pertama, dalam hal ini pemerolehan fonem bahasa ibu. Dalam perjalanannya, walaupun masih beberapa bunyi konsonan yang belum mampu dia ucapkan. Misalnya fonem $/ \mathrm{k} /$ yang seharus sudah mampu diucapkan, ternyata masih belum. Memang umur bukan menjadi patokan satu-satunya, namun faktor biologi dan neorologi yang hendaknya dijadikan patokan dalam melihat sejauh mana pemerolehan bahasa. Sebab, tidak semua anak mengalami perkembangan biologi dan neorologi yang sama. Di mana dalam perkembangan biologinya berhubungan dengan organ fisik artikulasi. Sedangkan dalam neurologi mengkaji kaitan antara otak dengan bahasa. Di mana ada bagian, bagian otak yang mengurus aktivitas beerbahasa. Oleh karena itu, yang jelas setiap anak mempunyai kemampuan berbahasa dan akan terus mengalami perkembangan dalam pemerolehan bahasanya (terlepas dari gangguan wicara).

Dalam proses pemerolehan bahasa tidak akan terlepas dari faktor yang memperngaruhinya, baik dari dalam maupun dari lingkungan bahasa. Faktor yang dari dalam tentunya berkaitan dengan kodrat yang sudah ada pada setiap diri manusia. Dengan artian bahwa manusia sudah memiliki kemampuan berbahasa. Hal ini didukung dengan kajian secara biologi dan neorologi. Akan tetapi, kurang tepat apabila kita mengabaikan faktor luar/lingkungan bahasa. Faktor luar ini berkaitan dengan apa yang dimaksud dengan stimulus respon. Artinya saat anak dalam proses pemerolehan bahasanya memerlukan stimulus atau masukan dari lingkungan bahasanya. Begitu pun yang terjadi pada Rasyid Hidayat, bahwa dia sudah memiliki apa yang namanya sistem bahasa atau piranti. Tetapi, kalau hanya sekedar piranti tanpa ada masukan dari luar akan sulit untuk memunculkan kemampuan berbahasa. Dalam perkembangannya dia terus belajar dari lingkungan sekitar selama proses pemerolehan bahasa pertamanya. Oleh karena itu, kedua hal tersebut harus mampu dipandang dari berbagai sudut pandang, sehingga tidak mengabaikan keuda atau salah satunya.

\section{DAFTAR PUSTAKA}

Arifuddin. 2010. Neuropsikolinguistik. Jakarta: Rajawali Pers.

Chaer, Abdul. 2009. Psikolinguistik: Kajian Teoretik. Jakarta: Renika Cipta.

Dardjowidjojo, Soenjono. 2000. ECHA: Kisah Pemerolehan Bahasa Anak Indonesia. Jakarta: Gramedia Widiasarana Indonesia.

Dardjowidjojo, Soenjono. 2016. Psikolinguistik: Pengantar Pemahaman Bahasa Manusia. Jakarta: Yayasan Pustaka Obor Indonesia.

Fatmawati, Suci Rani. 2015. "Pemerolehan Bahasa Pertama Anak Menurut Tinjauan Psikolinguistik". Lentera Vol 17, No 1 Juni (2015): LENTERA (Fakultas Ushuluddin, Adab, dan Dakwah IAIN Samarinda).

Kesuma, Tri Mastoyo Jati. 2007. Pengantar (Metode) Penelitian Bahasa. Yogyakarta: Carasvatibooks.

Mahsun. 2014. Metode Penelitian Bahasa: Tahap Strategi, Metode, dan Tekniknya. Jakarta: PT RajaGrafindo Persada.

Salamah, Siti. 2015. "Studi Ringkas Pemerolehan Bahasa Pada Anak". Bahastra Vol 33, No 2 (2015): Bahastra - Jurnal Ilmiah Bahasa dan Sastra (Universitas Ahmad Dahlan).

Sudika, I Nyoman. 2015. Psikolinguistik: Suatu Pengantar. Mataram: Universitas Mataram Press. 
Sugiyono. 2015. Metode Penelitian Pendidikan: Pendekatan Kuantitatif, Kualitatif, dan R\&D. Bandung: Alfabeta

Suryabrata, Sumadi. 2006. Metodologi Penelitian. Jakarta: Raja Grafindo Persada.

Tarigan, Henry Guntur. 1984. Psikolinguistik. Bandung: Angkas Bandung.

Tarigan, Henry Guntur.201l. Pengajaran Pemerolehan Bahasa. Bandung: Angkasa Bandung.

Tussolekha, Rohmah. 2015. "Mekanisme Pemerolehan Bahasa Pada Anak Usia Satu Dan Lima Tahun”. Jurnal Pesona Vol 1, No 2 (2015): (Pendidikan Bahasa dan Sastra Indonesia, STKIP Muhammadiyah Pringsewu).

Yogatama, Adiprana. 2011. "Pemerolehan Bahasa Pada Anak Usia 3 Tahun Ditinjau Dari Sudut Pandang Morfosintaksis". Lensa Vol 1, No 1 (2011): Kajian Kebahasaan, Kesusastraan, dan Budaya. (Universitas Muhammadiyah Semarang). 